\title{
Establishment of Virus-Induced Gene Silencing (VIGS) System in Perennial Rosa Plants under Field Conditions
}

\author{
Xiaoming Sui ${ }^{1 \#, ~ S h i k u a n ~ Y a n ' \#, ~ X u ~ H a n 1, ~ M i n g y u a n ~ Z h a o ' ~}{ }^{1}$, Lanyong Zhao ${ }^{1 *}$, Zongda Xu ${ }^{1^{*}}$ \\ ${ }^{1}$ College of Forestry, Shandong Agricultural University, Tai'an, China; ${ }^{2}$ Shandong Jing Liang Industry and Trade Co., \\ Ltd., Jinan, China
}

Correspondence to: Lanyong Zhao, sdzly369@163.com ; Zongda Xu, xuzoda@163.com Keywords: VIGS, Rosa, RrGT1 Gene, Field Conditions, Anthocyanin

Received: August 8, 2018 Accepted: September 2, $2018 \quad$ Published: September 5, 2018

Copyright (๑) 2018 by authors and Scientific Research Publishing Inc.

This work is licensed under the Creative Commons Attribution International License (CC BY 4.0).

http://creativecommons.org/licenses/by/4.0/

\section{(c) (i) Open Access}

\section{ABSTRACT}

Virus-induced gene silencing (VIGS) technique, which is developed in recent years, is a rapid identification of plant gene function from reverse genetics. It is a manifestation of post-transcriptional gene silencing mechanism. Compared with the traditional transgenic technology, VIGS is a transient expression system, which can achieve good results in a short time. At present, it is widely used to study the function of plant genes, but most of them are model plants, and the experiments are carried out always in the indoor environment with controlled light and temperature conditions. In this study, we creatively provided a method to establish VIGS system using perennial Rosa plants as experimental materials under field conditions. The recombinant virus vector was constructed with $R r G T 1$ gene as reporter gene and modified TRV-GFP virus as vector, and the perennial $R$. rugosa "Zizhi" and $R$. davurica were used as experimental verification materials. According to the growth conditions of Rosa plants, the natural environment in the field and the optimal conditions for the occurrence of VIGS, the technical problems such as the confirmation of the inoculation period, the preparation of the infective fluid, the inoculation technology of the virus vector and the light and temperature conditions of plant materials cultured after inoculation were solved one by one. When the RrGT1 gene was silenced, the Rosa plants showed a pale petal color phenotype. By detection, it was found that the expression of endogenous $R r G T 1$ gene was significantly down-regulated, and the content of all anthocyanins also decreased significantly. Therefore, we believed that the attempt to establish VIGS system in perennial Rosa plants under field conditions was very successful.

\section{INTRODUCTION}

Many plants in the genus Rosa, such as Rosa rugosa, Rosa chinensis and Rosa davidiana, have great \#These authors contribute equally.

${ }^{\star}$ Corresponding authors. 
scientific research value. However, traditional hybrid breeding is still the main method in the study of many important characters (flower color, flower fragrance, etc.). With the development of functional genomics, more and more attention has been paid to the study of key genes that control traits. However, the method of gene function verification is very simple, the most widely used is transgenic technology [1-3]. For some plants that have not solved the problem of tissue culture, the implementation of transgenic technology is usually based on model plants, such as Arabidopsis thaliana and tobacco, as experimental materials. But for the key genes controlling flower color, flower fragrance, and other ornamental characters in the plants that were the subject of the study, even if the change of characters is observed in transgenic model plants, it cannot be equated with the characters of the plants themselves as the object of study. This is also a major restriction on the use of transgenic technology to verify gene function.

In addition to using transgenic technology to study the function of genes, virus-induced gene silencing (VIGS) is also an efficient genetic tool for functional genomics in plants. Usually, VIGS needs to construct a recombinant virus carrying a fragment of the target gene to silence a specific endogenous gene [4]. The host defense machinery, such as post-transcriptional gene silencing (PTGS), will be activated when the virus invades the host plant. PTGS will target double-stranded RNA (dsRNA), which is commonly used for replication of most plant viruses, and lead to cleavage of dsRNA and sequential generation of small interfering RNA (siRNA). The siRNAs are loaded into the RNAi silencing complex (RISC) to degrade any endogenous transcript which shows sequence homology to the siRNA [5-7]. In general, VIGS has become a simple and fast method to study gene function because of its simplicity and efficiency.

However, VIGS technology also has its limitations. Due to the limitation of host range, different host plants may need to select corresponding virus vectors, and different virus vectors may have different requirements for the length of inserted exogenous gene fragments [8]. In addition, the sensitivity of plant materials to virus vectors also determines the method of introducing virus vectors suitable for use in plant materials. And the optimal plant culture temperature, the circadian growth rhythm and the optimum propagation temperature of the virus carrier determine the light and temperature conditions of the whole experimental system [9]. These uncertainties directly lead to the possibility that different genera and even different species of the same genus may need an independent VIGS operating system, but cannot use the same set of universal VIGS system simply to achieve the purpose of efficient silencing function gene.

For the selection of viral vectors, the most widely used vector is TRV virus. It is applicable for many plants because the virus has a broad host range [10]. TRV virus is a double-stranded RNA virus [11]. The modified TRV-GFP vectors are also widely used because of its small molecular weight, wide host range, high infection rate, low pathogenicity and green fluorescence visualization after infection.

At present, there are many inoculation methods for VIGS, and the following are commonly used: vacuum infiltration method, high pressure spray gun method (leaf surface direct spraying method), root absorption method (root irrigation method), back leaf injection method, etc. Generally speaking, the vacuum infiltration method has the highest silencing efficiency, but it has a high demand for utensils and cannot be used under the condition of the field. Although the high pressure spray gun method can be operated in a large area, because the leaves of Rosa are smaller and fluffier in the inoculation period, the contact area between the liquid and the blade is small and cannot penetrate the leaf surface.

The root absorption method is simple, but the species limitation is higher, so it is not suitable for Rosa. In addition, high pressure spray gun method and root absorption method need to consume a large amount of infection liquid, which is also not suitable for operation under field conditions. Although the operation of leaf back injection is relatively simple, it cannot be injected with syringe because of the shallow leaves of Rosa.

In order to solve the technical problems mentioned above, in this study, we provided a method for establishing VIGS system based on perennial Rosa plants as experimental objects under field conditions. According to the growth conditions of Rosa plants, the natural environment in the field and the optimal conditions for the occurrence of VIGS, the technical problems were solved one by one. And the successful establishment of VIGS system was confirmed by determining some biochemical indexes. 


\section{MATERIALS AND METHODS}

\subsection{Plant Materials}

For Rosa, R. rugosa "Zizhi" and $R$. davurica cultivated in Rose germplasm nursery of Shandong Agricultural University was used as the test material. We collected the samples (leaves and petals) in the forenoon on sunny days from 20 April to 10 May 2017. After quick freezing of liquid nitrogen, all samples collected with three replicates were put into $-80^{\circ} \mathrm{C}$ refrigerator for storage.

\subsection{Extraction of Total RNA and Synthesis of the First-Strand cDNA}

The extraction of total RNA is based on the specification of EASY spin plant RNA rapid extraction kit (Aidlab Biotech, Beijing, China). The integrity of RNA was detected by gel electrophoresis with 1.0\% nondenatured agarose, the purity and concentration of RNA were detected by Nanodrop2000C ultramicro spectrophotometer (Thermo Fisher Scientific, Wilmington, Delaware, USA), and the qualified RNA was preserved at $-80^{\circ} \mathrm{C}$. The first-strand cDNA was synthesized by referring to the steps of $5 \times$ All-In-One RT MasterMix reverse transcription kit (ABM Company,Vancouver, Canada) and synthesized according to the requirements of RT-PCR and qRT-PCR.

\subsection{VIGS in R. rugosa}

Based on the modified TRV-GFP vector, the recombinant viral vector TRV-GFP-RrGT1 was constructed. pTRV1 and pTRV2-GFP are two RNA strands of TRV-GFP virus vector respectively, and the multiple clone site are mainly on pTRV2-GFP. In order to specifically silence the RrGT1 gene in $R$. rugosa, the relative conserved region of the $R r G T 1$ gene was removed, and a sequence of the length of 543bp was finally selected as the specific fragment, by analyzing the conserved domain of the $R r G T 1$ gene. Two restriction endonuclease sites ( $\mathrm{XbaI}$ and $\mathrm{Xhol}$ ) were designed at the two ends of the fragment. After double enzyme digestion, the digestion products were ligated with DNA ligase and transformed into Agrobacterium tumefaciens. The recombinant viral vector was confirmed by PCR and sequencing.

The plasmids of pTRV1, pTRV2-GFP and pTRV2-GFP-RrGT1 were transformed into $A$. tumefaciens, and cultured in YEB medium containing kanamycin, rifampicin and AS at $28^{\circ} \mathrm{C}$ for $14-16 \mathrm{~h}$ to reach $\mathrm{OD}_{600}=1.5$. Before the infection, the $A$. tumefaciens infective liquid with pTRV2-GFP and pTRV2-GFP-RrGT1 was mixed with the $A$. tumefaciens infective liquid carrying pTRV1 in equal volume respectively to form the complete TRV-GFP and TRV-GFP-RrGT1 virus carrier. Then the mixed bacteria solution was kept at room temperature for $4 \mathrm{~h}$ with darkness.

The experimental materials for gene silencing induced by virus were the perennial Rosa plants grown naturally in the field, and the experimental treatment time was about one month before Rosa flowering. Because the leaves and twigs are difficult to be injected with syringes and vacuum infiltration cannot be used in the field, we have adopted the method of infecting leaves and twigs with $A$. tumefaciens after scratching them. The specific operation was to completely immerse the scratched leaves and branchlets in the $5 \mathrm{ml}$ centrifuge tube containing the infective fluid for infection. In order to improve the infection efficiency of $A$. tumefaciens, $0.01 \%$ Silwet L-77 was added to the infective fluid and the plants was treated with black plastic bags for $24 \mathrm{~h}$ after the infection for $10 \mathrm{~min}$.

\section{4. qRT-PCR Detection}

We analyzed the gene expression by qRT-PCR on a Bio-Rad CFX96 ${ }^{\mathrm{TM}}$ Real-Time PCR instrument (Bio-Rad, Inc., USA). The qRT-PCR mixture (20 $\mu \mathrm{L}$ total volume) contained $10 \mu \mathrm{L}$ of SYBR ${ }^{\oplus}$ Premix Ex $\mathrm{Taq}^{\mathrm{Tm}}$ (TaKaRa, Inc., Japan), $8.2 \mu \mathrm{L}$ of $\mathrm{ddH}_{2} \mathrm{O}, 0.4 \mu \mathrm{L}$ of each primer and $1 \mu \mathrm{L}$ of cDNA. The PCR program was carried out with an initial step of $95^{\circ} \mathrm{C}$ for $30 \mathrm{~s} ; 40$ cycles of $95^{\circ} \mathrm{C}$ for $5 \mathrm{~s}, 60^{\circ} \mathrm{C}$ for $30 \mathrm{~s}$; and then, $95^{\circ} \mathrm{C}$ for $10 \mathrm{~s}, 65^{\circ} \mathrm{C}$ for $5 \mathrm{~s}$ and $95^{\circ} \mathrm{C}$ for $5 \mathrm{~s}$ for the dissociation stage. Each gene was assessed with three biological replications. The relative expression levels of the genes were calculated by the $2^{-\Delta \Delta \mathrm{Ct}}$ method [12]. 


\subsection{Total Anthocyanin Extractions and HPLC Analysis}

All samples $(0.1 \mathrm{~g}$ fresh weight $)$ were homogenized in liquid nitrogen, after which they were extracted with $5 \mathrm{~mL}$ of an acidic methanol solution (70:0.1:29.9, v/v/v; $\left.\mathrm{CH}_{3} \mathrm{OH}: \mathrm{HCl}: \mathrm{H}_{2} \mathrm{O}\right)$ at $4^{\circ} \mathrm{C}$ in darkness for $24 \mathrm{~h}$ and then sonicated for $30 \mathrm{~min}$. After centrifugation, each extract was passed through a membrane filter $(0.22 \mathrm{~mm})$. The aqueous phase was used to determine the absorbance at $530 \mathrm{~nm}$ and $657 \mathrm{~nm}$. The total anthocyanin contents were quantified via the following equation: $Q_{\text {Anthocyanins }}=\left(A_{530}-0.25 \times A_{657}\right) \times M^{-1}$, where $\mathrm{Q}_{\text {Anthocyanins }}$ is the amount of anthocyanins, $\mathrm{A}_{530}$ and $\mathrm{A}_{657}$ are the absorptions at the indicated wavelengths, and $\mathrm{M}$ is the weight of the plant material in grams used for extraction.

Qualitative and quantitative analyses of anthocyanins were performed via HPLC. Three independent biological replicates were measured for each sample. The specific conditions of the anthocyanin analysis were the same as those in the report of Yang et al. with some modifications [13]. The chromatographic analysis was conducted using an Agilent 1100 series HPLC system (TC-C18 column, $5 \mu \mathrm{m}, 4.6 \mathrm{~mm} \times 250$ $\mathrm{mm}$ ) with the detection wavelength at $530 \mathrm{~nm}$ and the column was maintained at $30^{\circ} \mathrm{C}$. The eluent was aqueous solution $\mathrm{A}$ ( $0.1 \%$ formic acid in water) and organic solvent $\mathrm{B}$ (acetonitrile). The gradient elution program was modified as follows: $0 \mathrm{~min}, 10 \% \mathrm{~B} ; 15 \mathrm{~min}, 17 \% \mathrm{~B} ; 20 \mathrm{~min}, 23 \% \mathrm{~B} ; 25 \mathrm{~min}, 23 \% \mathrm{~B}$; and $30 \mathrm{~min}$, $10 \% \mathrm{~B}$; the eluent flow rate was $1.0 \mathrm{ml} / \mathrm{min}$ with $10 \mu \mathrm{l}$ injection volume. Cy3G, Cy3G5G, Pg3G, Pg3G5G, Pn3G, Pn3G5G, Dp3G and Dp3G5G were used as references for the anthocyanin analysis.

\section{RESULTS}

\subsection{Construction and Verification of Recombinant Virus Vector pTRV2-GFP-RrGT1}

The virus vector pTRV2-GFP and the specific fragment of the $R r G T 1$ gene were respectively digested (Figure 1(a)) and then were combined together. Then the PCR (Figure 1(b)) was verified by specific primers (Table 1), and the base mutation and deletion were verified by double enzyme digestion (Figure 1(c)) and sequencing. All of the above results indicated that the recombinant virus vector pTRV2-GFP-RrGT1 was successfully constructed.

\subsection{VIGS of RrGT1 Gene Reduced the Transcription Abundance of Endogenous RrGT1 Gene}

At 14 days after infection, the leaves of control plants and the infected plants (TRV-GFP and TRV-GFP-RrGT1) were collected for semiquantitative RT-PCR detection, and the RrGAPDH gene was used as internal control to confirm the efficiency of VIGS. The results (Figure 2(a)) showed that $T R V$ and GFP genes could be detected in leaves treated with VIGS (TRV-GFP and TRV-GFP-RrGT1), but the abundance of the $R r G T 1$ gene was significantly decreased only in leaves treated with TRV-GFP-RrGT1, and the expression of the $R r G T 1$ gene was normal in the leaves treated with TRV-GFP. While in the control group, the $T R V$ and $G F P$ genes could not be detected and the $R r G T 1$ gene was normally expressed.

At 30 - 40 days after infection, in vitro observation, semiquantitative RT-PCR and qRT-PCR were performed on the blooming petals of control plants and the infected plants (TRV-GFP and TRV-GFP-RrGT1) of two Rosa species. The results were as expected: we can clearly observe that the control group and TRV-GFP group had no obvious change of flower color, but the TRV-GFP-RrGT1 group had obviously shallower petals (Figure 3(a)). The presences of $T R V$ virus and $G F P$ gene could be detected in the petals treated with VIGS (TRV-GFP and TRV-GFP-RrGT1). In the petals treated with TRV-GFP-RrGT1, the expression of $R r G T 1$ gene was almost not detected, but was normal in the petals treated with TRV-GFP; in contrast, $T R V$ and GFP genes were not detected in the control group, and the RrGT1 gene was expressed normally (Figure 2(b)). The results of the qRT-PCR detection (Figure 3(b)) were consistent with the results above. In the two Rosa species, the trend of relative expression of $R r G T 1$ gene is also basically consistent: the relative expression level of $\operatorname{RrGT1}$ gene in the petals treated with TRV-GFP was basically the same as that in control group. However, the transcription abundance of endogenous $R r G T 1$ gene in petals treated with TRV-GFP-RrGT1 was significantly downregulated. 


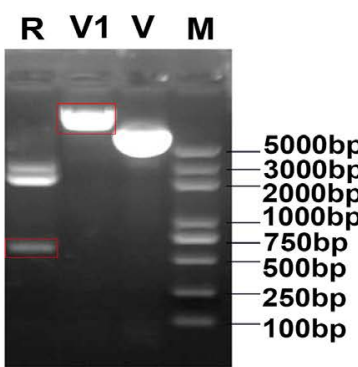

(a)

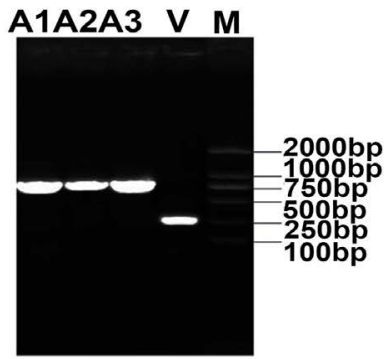

(b)

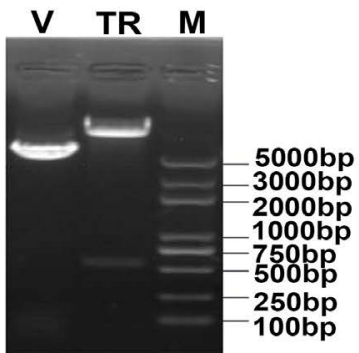

(c)

Figure 1. Construction and validation of the recombinant virus vector TRV-GFP-RrGT1. (a) The virus vector and target gene fragment were digested separately. M: Marker; V: The plasmid of the empty virus vector was used as the control; V1: The empty virus vector was digested by double enzymes; R: The plasmid carrying the target gene fragment was digested by two enzymes. The red box indicates the portion that needs to be retained for subsequent operations. (b) The result of PCR verification. Three repeated PCR assays were performed on the recombinant virus vector and the results showed positive. M: Marker; V: The empty virus vector was used as the control; A1, A2, A3 was the three repetitions which were larger than the empty virus vector due to the inserted $R r G T 1$ fragment. (c) Double enzyme digestion was used to verify the plasmid of the recombinant vector. M: Marker; V: The plasmid of the empty virus vector was used as the control; TR: The plasmid of the recombinant vector was digested into two correct parts.

Table 1. Primers used in the present study.

\begin{tabular}{|c|c|c|}
\hline Primer Name & Sequence( $\left.5^{\prime}-3^{\prime}\right)$ & Description \\
\hline TGR-F & GCTCTAGAATGTCAGGAAATCCACTGGATGC & Generation for $p T R V 2-G F P-R r G T 1$ \\
\hline TGR-R & CCCTCGAGCTGCAGTGGTAATGAGAGGGAG & \\
\hline$T R V 1-\mathrm{F}$ & TTACAGGTTATTTGGGCTAG & RT-PCR for $T R V 1$ \\
\hline$T R V 1-\mathrm{R}$ & CCGGGTTCAATTCCTTATC & \multirow{5}{*}{$\begin{array}{l}\text { Confirmation for recombinant } \\
\text { silencing vector and RT-PCR for } \\
T R V 2 \text { RT-PCR for } G F P\end{array}$} \\
\hline$T R V 2-\mathrm{F}$ & TGGGAGATGATACGCTGTT & \\
\hline$T R V 2-\mathrm{R}$ & CCTAAAACTTCAGACACG & \\
\hline$G F P-\mathrm{F}$ & ATGGTGAGCAAGGGCGAGGA & \\
\hline$G F P-\mathrm{R}$ & CTTGTACAGCTCGTCCATGCC & \\
\hline $\operatorname{RrGAPDH-\mathrm {F}}$ & TTCTGCCTGCTCTCAATG & \multirow[t]{2}{*}{ RT-PCR and qRT-PCR for $R r G A P D H$} \\
\hline $\operatorname{RrGAPDH-\mathrm {R}}$ & TGCCTTCTTCTCAAGTCTG & \\
\hline $\mathrm{q} R r G T 1-\mathrm{F}$ & GTATTTGCCAACACACTGAGTAA & qRT-PCR for $R r G T 1$ \\
\hline $\mathrm{q} R r G T 1-\mathrm{R}$ & CTGCAGTGGTAATGAGAGGGAG & \\
\hline
\end{tabular}

${ }^{\star}$ Restriction enzyme site are underlined.

\subsection{Silencing Efficiency of VIGS}

Total RNA was extracted from all petals of VIGS treated samples and the first strand cDNA was synthesized. The results of PCR and agarose gel electrophoresis showed that: The silencing efficiency of VIGS was $75 \%$ in $R$. rugosa "Zizhi" and $85 \%$ in $R$. davurica (Table 2). 


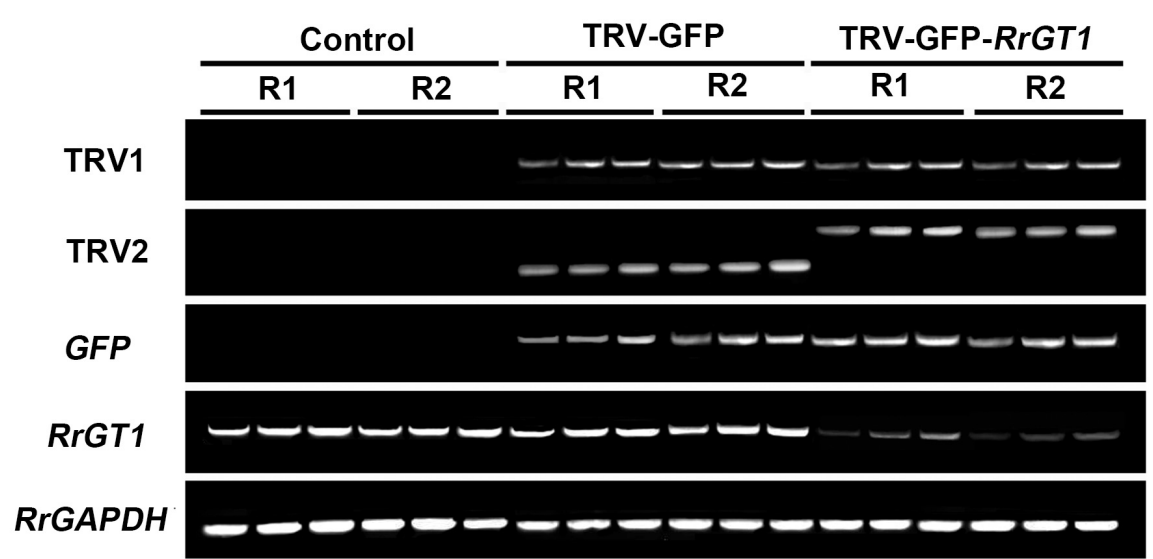

(a)

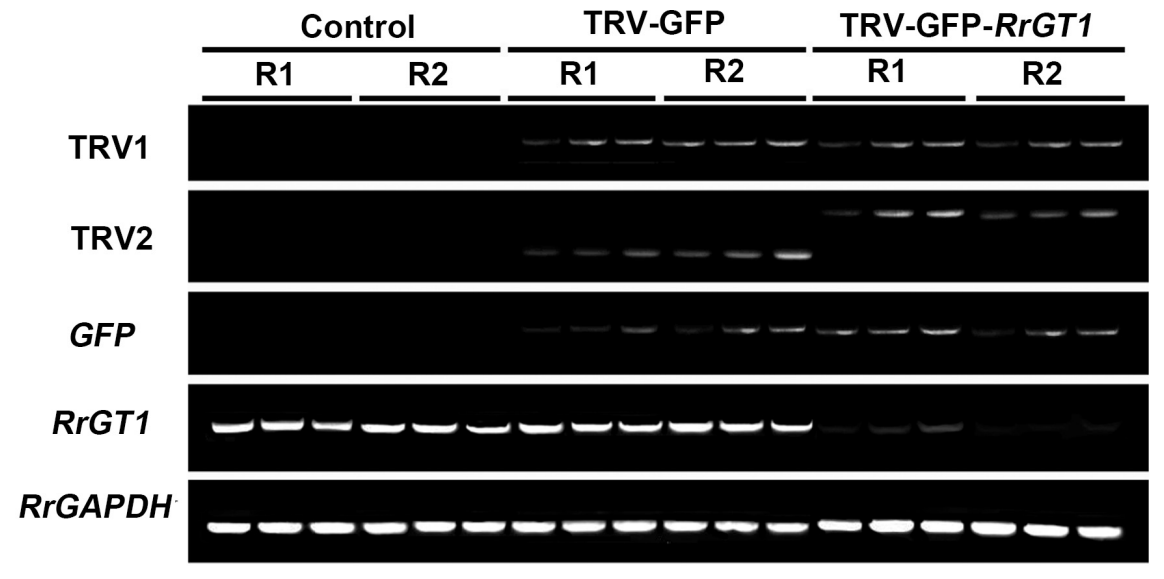

(b)

Figure 2. Semiquantitative RT-PCR in leaves (a) and petals (b). Semiquantitative RT-PCR of $T R V 1, T R V 2, G F P$, and $R r G T 1$ in control group and VIGS-treated group. R1, $R$. rugosa "Zizhi"; R2, $R$. davurica. $\operatorname{RrGAPDH}$ was used as an internal control. The TRV2 fragment was larger in plants infected by TRV-GFP-RrGT1 due to the inserted $R r G T 1$ fragment.

\subsection{HPLC Analysis}

The anthocyanin HPLC chromatograms for R. rugosa "Zizhi" (Figure 3(c)) and $R$. davurica (Figure $3(d))$ show that the components were well separated. Comparisons with standards allow the contents of different substances to be calculated by their peak area (Table 3). For "Zizhi", six kinds of anthocyanins were detected: Cy3G5G, Pg3G5G, Cy3G, Pn3G5G, Pg3G, and Pn3G. Pn3G5G had the highest content, while Cy3G5G had the second highest; the contents of the other four anthocyanins were relatively low. In response to VIGS treatment, reductions in the contents of several anthocyanins compared with those in the control group and TRV-GFP group were obvious. Pn3G5G exhibited the greatest drop in content, followed by Cy3G5G; the content in Pg3G was no longer detectable. For $R$. davurica, the six anthocyanins listed above were also detected. However, Cy3G5G had the highest content, and Cy3G had the second highest content; the contents of the other four anthocyanins were relatively low. In response to VIGS treatment, reductions in the contents of the six anthocyanins compared with those in the control group and TRV-GFP group were obvious. Cy3G5G exhibited the greatest drop in content, followed by Cy3G; no detection of Pn3G was observed. 


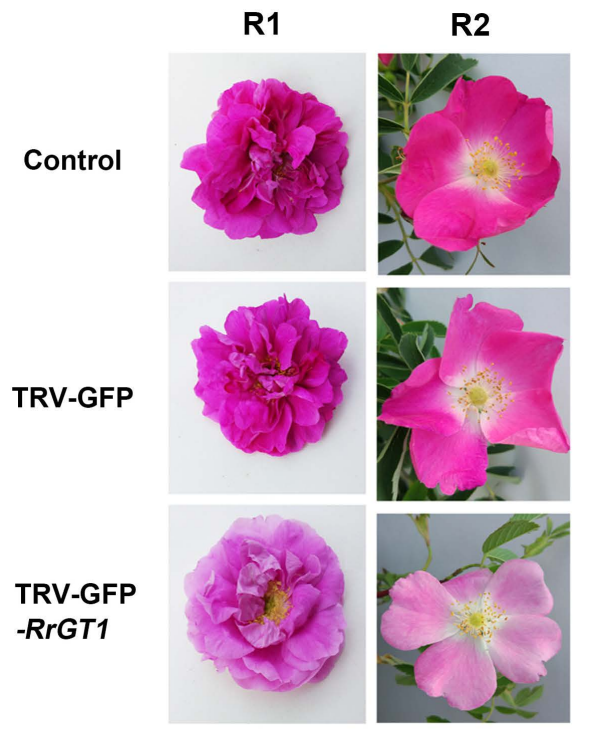

(a)
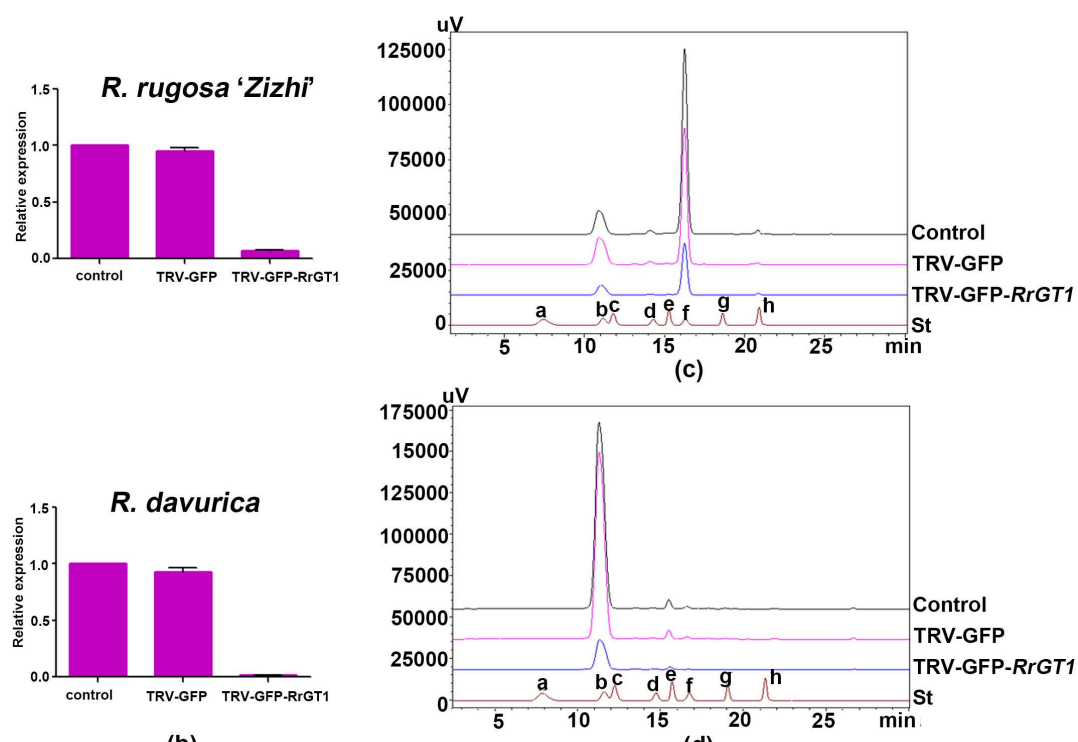

(d)

Figure 3. Validation of VIGS in flowers of $R$. rugosa "Zizhi" and $R$. davurica. (a) Contrast of flower color phenotypes. R1, $R$. rugosa "Zizhi"; R2, $R$. davurica. (b) The results of the qRT-PCR detection. The error bars represent the SDs of triplicate reactions. The experiment was repeated three times, and each yielded similar results. HPLC chromatograms in $R$. rugosa "Zizhi" (c) and $R$. davurica (d). Eight kinds of anthocyanin standards (St) were used for detection: (a) Dp3G5G; (b) Cy3G5G; (c) Dp3G; (d) Pg3G5G; (e) Cy3G; (f) Pn3G5G; (g) Pg3G; and (h) Pn3G.

Table 2. Silencing efficiency of VIGS in $R$. rugosa "Zizhi" and $R$. davurica.

\begin{tabular}{cccc}
\hline Plant & & TRV-GFP & TRV-GFP- $R r G T 1$ \\
\hline \multirow{2}{*}{ R. rugosa "Zizhi" } & Total & 20 & 20 \\
& GFP positive & 17 & 15 \\
& RrGT1 silencing & - & 15 \\
& GSEI & - & $75 \%$ \\
& Total & 20 & 20 \\
& GFP positive & 18 & 17 \\
& RrGT1 silencing & - & 17 \\
& GSEI & - & $85 \%$ \\
\hline
\end{tabular}

GSEI, gene silencing efficiency of all infected plants.

\section{DISCUSSION}

In the past few years, molecular biology has made great progress in model plants and crops. However, the molecular biology of Rosa lags far behind. One reason is that the Rosa genera are usually perennial woody plants, usually taking a long time to achieve results, and another reason is that the transgenic operation of the Rosa genus is difficult.

As a simple and rapid tool in functional genomics, VIGS has been widely used to analyze gene function in many plant species, as well as in multiple development processes and in response to extrinsic stimuli. Therefore, in the past decade, tremendous improvements VIGS have been reported, such as 
Table 3. Contents of anthocyanins in the flowers of $R$. rugosa "Zizhi" and $R$. davurica subjected to different VIGS treatments $\left(\mu \mathrm{g} \cdot \mathrm{g}^{-1} \mathrm{FW}\right)$.

\begin{tabular}{|c|c|c|c|c|c|c|c|c|c|}
\hline Name & treatments & Су3G & Cy3G5G & Pn3G & Pn3G5G & $\operatorname{Pg} 3 \mathrm{G}$ & Pg3G5G & Dp3G & Dp3G5G \\
\hline \multirow{3}{*}{$\begin{array}{l}\text { R. rugosa } \\
\text { "Zizhi” }\end{array}$} & Control & $\begin{array}{c}13.05 \pm \\
0.04 \mathrm{~A}\end{array}$ & $\begin{array}{c}298.38 \pm \\
3.85 \mathrm{~A}\end{array}$ & $\begin{array}{c}17.63 \pm \\
0.12 \mathrm{~A}\end{array}$ & $\begin{array}{c}1773.93 \pm \\
4.31 \mathrm{~A}\end{array}$ & $\begin{array}{l}5.04 \pm \\
0.09 \mathrm{~A}\end{array}$ & $\begin{array}{c}52.88 \pm \\
0.45 \mathrm{~A}\end{array}$ & - & - \\
\hline & TRV-GFP & $\begin{array}{c}11.86 \pm \\
0.70 \mathrm{~A}\end{array}$ & $\begin{array}{c}301.14 \pm \\
1.57 \mathrm{~A}\end{array}$ & $\begin{array}{c}17.33 \pm \\
0.07 \mathrm{~A}\end{array}$ & $\begin{array}{c}1660.26 \pm \\
13.07 \mathrm{~B}\end{array}$ & $\begin{array}{l}4.82 \pm \\
0.13 \mathrm{~A}\end{array}$ & $\begin{array}{c}45.32 \pm \\
1.23 \mathrm{~B}\end{array}$ & - & - \\
\hline & $\begin{array}{c}\text { TRV-GFP- } R r \\
G T 1\end{array}$ & $\begin{array}{l}3.22 \pm \\
0.12 \mathrm{~B}\end{array}$ & $\begin{array}{c}96.17 \pm \\
2.22 \mathrm{~B}\end{array}$ & $\begin{array}{l}5.16 \pm \\
0.06 \mathrm{~B}\end{array}$ & $\begin{array}{c}472.31 \pm \\
1.28 \mathrm{C}\end{array}$ & - & $\begin{array}{c}10.84 \pm \\
0.39 \mathrm{C}\end{array}$ & - & - \\
\hline \multirow{3}{*}{$R$. davurica } & Control & $\begin{array}{c}56.72 \pm \\
0.20 \mathrm{~A}\end{array}$ & $\begin{array}{c}2590.18 \pm \\
2.45 \mathrm{~A}\end{array}$ & $\begin{array}{l}2.55 \pm \\
0.03 \mathrm{~A}\end{array}$ & $\begin{array}{c}40.28 \pm \\
0.09 \mathrm{~A}\end{array}$ & $\begin{array}{l}7.20 \pm \\
0.01 \mathrm{~A}\end{array}$ & $\begin{array}{c}25.7 \pm \\
0.36 \mathrm{~B}\end{array}$ & - & - \\
\hline & TRV-GFP & $\begin{array}{c}55.59 \pm \\
0.26 \mathrm{~B}\end{array}$ & $\begin{array}{c}2565.85 \pm \\
3.26 \mathrm{~B}\end{array}$ & $\begin{array}{l}2.50 \pm \\
0.01 \mathrm{~A}\end{array}$ & $\begin{array}{c}40.36 \pm \\
0.11 \mathrm{~A}\end{array}$ & $\begin{array}{l}7.19 \pm \\
0.01 \mathrm{~A}\end{array}$ & $\begin{array}{c}28.13 \pm \\
0.27 \mathrm{~A}\end{array}$ & - & - \\
\hline & $\begin{array}{c}\text { TRV-GFP- } R r \\
G T 1\end{array}$ & $\begin{array}{c}15.33 \pm \\
0.17 \mathrm{C}\end{array}$ & $\begin{array}{c}443.17 \pm \\
4.04 \mathrm{C}\end{array}$ & - & $\begin{array}{l}1.95 \pm \\
0.02 \mathrm{~B}\end{array}$ & $\begin{array}{c}0.74 \pm \\
0.03 \mathrm{~B}\end{array}$ & $\begin{array}{l}6.99 \pm \\
0.06 \mathrm{C}\end{array}$ & - & - \\
\hline
\end{tabular}

${ }^{*}$ Data are the mean values \pm SE of three independent replicates. Different upper case letters represent significant difference which is calculated using LSD analysis at the level of $\mathrm{P}<0.01$. “"” means that no corresponding anthocyanin was detected.

developing new vectors and improving the vector delivery methods $[14,15]$. At present, few reports exist about the use of the VIGS system in plant floral organs, and most of the tested species belong to the Solanaceae family. For example, VIGS technology was used to study the genes controlling floral fragrance in Petunia hybrida [16], and the roles of the SIMADSI, NbMADS4-1 and NbMADS4-2 genes in tobacco flowers were also identified via the VIGS [17]. Furthermore, the TRV recombinant virus vector successfully induced the silencing of the CHS gene and GLO1 gene in Gerbera jamesonii [18]. In this study, we developed a VIGS system for use with perennial Rosa plants grown naturally in the field as experimental materials for the first time, and we used the system to study key genes of Rosa color and obtained results.

At present, the main factors affecting gene silencing effect are summarized as follows: firstly, the matching degree between virus vector and target plant; Secondly, the position of the target gene fragment inserted into the virus vector and the length of the target gene fragment in the whole length of the gene; thirdly, the determination of the inoculation period, the preparation of the infective fluid, the inoculation technology of the virus vector and the light and temperature conditions of plant materials cultured after inoculation after the construction of the recombinant virus vector with the target gene $[19,20]$.

In this study, according to the optimum conditions of VIGS in field, we select the most suitable virus vector, the best growth stage of Rosa plants inoculation, the best method of preparation of infective liquid, the most suitable inoculation method and the most reasonable culture management method after inoculation in order to achieve the most efficient gene silencing effect. Because of the influence of natural environment under field conditions and the ability of resistance to infection of perennial plant materials, we increased the concentration of A. tumefaciens carrying virus vector in the preparation of infective fluid. In order to ensure the sufficient survival base of A. tumefaciens carrying virus vector in the inoculation area under natural conditions, so as to improve the infection efficiency of the whole experiment. The use of low concentration Silwet L-77 in the formulation of infective liquid also achieved a good effect, which not only increased the hydrophilicity of plant material surface, but also increased the infection efficiency of the infective liquid. Moreover, low concentration of components will not produce toxic effect on plant materials, and its pollution rate is low, which is beneficial to environmental protection. The intensive scratching of the treatment site and the prolongation of the time of infiltration and infection can not only increase the 
area of contact between the wound and the infective fluid, but also improve the infection efficiency. Moreover, due to the strong growth of the treatment site, its normal growth will not be greatly affected by the condition that it is not broken and incomplete. The bagging dark treatment after inoculation can not only achieve the effect of heat preservation and moisture preservation, but also resist the bad weather to a certain extent.

In this study, we developed a VIGS system for use with perennial Rosa plants grown naturally in the field as experimental materials for the first time, and we used the system to study key genes of Rosa color and obtained results. Under conditions of the established optimal VIGS system, the petal color of both Rosa species was clearly lighter, which was consistent with the significantly downregulated transcript abundance of the endogenous $\operatorname{RrGT1}$ gene and the decrease in the contents of all the different kinds of anthocyanins after HPLC analysis. This undoubtedly proved that our attempt to establish VIGS system using perennial Rosa plants as experimental materials under field conditions was successful.

\section{CONCLUSION}

In conclusion, the construction of this VIGS system not only saved the cost but also improved the efficiency of gene silencing. The efficiency of gene silencing in the treatment of samples was more than $75 \%$, which will greatly promote the research in the field of genetic engineering in Rosa plants. It will also promote the transition from research objects to experimental verification materials and greatly reduce the time of gene function verification.

\section{ACKNOWLEDGEMENTS}

This project was supported by the Agricultural Seed Project of Shandong Province ([2014] No. 96).

\section{CONFLICTS OF INTEREST}

The authors declare that they have no conflicts of interest.

\section{REFERENCES}

1. Wang, J.Z. and Sun, S.L. (2002) The Research and Application Prospect of Bt Transgenic Plants. Journal of Beijing Agricultural College, 17, 61-65.

2. Chen, X.B., Zhang, A.P. and Yao, Q.H. (2001) Advances in Researches on Gene Engineering of Plant for Cold Resistance. Biotechnology Information, 4, 14-20.

3. Wang, C.X., Yang, M.Z., Pan, N.S. and Chen, Z.L. (1993) Resistance to Potato Virus X Infection in Transgenic Tobacco Plants with Coat Protein Gene of Virus. Journal of Integrative Plant Biology, 35, 819-824.

4. Kumagai, M.H., Donson, J., della-Cioppa, G., Harvey, D., Hanley, K. and Grill, L.K. (1995) Cytoplasmic Inhibition of Carotenoid Biosynthesis with Virus-Derived RNA. Proceedings of the National Academy of Sciences, 92 , 1679-1683. https://doi.org/10.1073/pnas.92.5.1679

5. Ruiz, M.T., Voinnet, O. and Baulcombe, D.C. (1998) Initiation and Maintenance of Virus-Induced Gene Silencing. The Plant Cell, 10, 937-946. https://doi.org/10.1105/tpc.10.6.937

6. Baulcombe, D.C. (1999) Fast Forward Genetics Based on Virus Induced Gene Silencing. Current Opinion in Plant Biology, 2, 109-113. https://doi.org/10.1016/S1369-5266(99)80022-3

7. Burch-Smith, T.M., Schiff, M., Liu, Y. and Dinesh-Kumar, S.P. (2006) Efficient Virus-Induced Gene Silencing in Arabidopsis. Plant Physiology, 142, 21-27. https://doi.org/10.1104/pp.106.084624

8. Yamagishi, N. and Yoshikawa, N. (2011) Virus-Induced Gene Silencing of Endogenous Genes and Promotion of Flowering in Soybean by Apple latent spherical Virus-Based Vectors. Soybean-Molecular Aspects of Breeding, 43-56. https://doi.org/10.5772/14568 
9. Nethra, P., Nataraja, K.N., Rama, N. and Udayakumar, M. (2006) Standardization of Environmental Conditions for Induction and Retention of Post Transcriptional Gene Silencing Using Tobacco rattle Virus Vector. Current Science, 90, 431-435.

10. Bachan, S. and Dinesh-Kumar, S.P. (2012) Tobacco Rattle Virus (TRV) Based Virus-Induced Gene Silencing. Methods in Molecular Biology, 894, 83-92. https://doi.org/10.1007/978-1-61779-882-5_6

11. Liu, Y., Schiff, M., Marathe, R. and Dinesh-Kumar, S.P. (2002) Tobacco Rar1, EDS1 and NPR1/NIM1 Like Genes Are Required for N-Mediated Resistance to Tobacco Mosaic Virus. The Plant Journal, 30, 415-429. https://doi.org/10.1046/j.1365-313X.2002.01297.x

12. Schmittgen, T.D. and Livak, K.J. (2008) Analyzing Real-Time PCR Data by the Comparative C(T) Method. Nature Protocols, 3, 1101. https://doi.org/10.1038/nprot.2008.73

13. Yang, Q., Yuan, T. and Sun, X.B. (2015) Preliminary Studies on the Changes of Flower Color during the Flowering Period in Two Tree Peony Cultivars. Acta Horticulturae Sinica, 42, 930-938.

14. Jiang, C.Z., Chen, J.C. and Reid, M. (2011) Virus-Induced Gene Silencing in Ornamental Plants. Methods in Molecular Biology, 744, 81-96. https://doi.org/10.1007/978-1-61779-123-9_6

15. Senthil-Kumar, M. and Mysore, K.S. (2011) New Dimensions for VIGS in Plant Functional Genomics. Trends in Plant Science, 16, 656-665. https://doi.org/10.1016/j.tplants.2011.08.006

16. Spitzer, B., Zvi, M.M.B., Ovadis, M., Marhevka, E., Barkai, O., Edelbaum, O., Marton, I., Masci, T., Alon, M., Morin, S., Rogachev, I., Aharoni, S. and Vainstein, A. (2007) Reverse Genetics of Floral Scent: Application of Tobacco Rattle Virus-Based Gene Silencing in Petunia. Plant Physiology, 145, 1241-1250. https://doi.org/10.1104/pp.107.105916

17. Dong, Y.Y., Burch-Smith, T.M., Liu, Y.L., Mamillapalli, P. and Dinesh-Kumar, S.P. (2007) A Ligation-Independent Cloning Tobacco Rattle Virus Vector for High-Throughput Virus-Induced Gene Silencing Identifies roles for NbMADS4-1 and -2 in Floral Development. Plant Physiology, 145, 1161-1170.

https://doi.org/10.1104/pp.107.107391

18. Deng, X.B., Elomaa, P., Nguyen, C.X., Hytonen, T., Valkonen, J.P.T. and Teeri, T.H. (2012) Virus-Induced Gene Silencing for Asteraceae: A Reverse Genetics Approach for Functional Genomics in Gerbera hybrida. Plant Biotechnology Journal, 10, 970-978. https://doi.org/10.1111/j.1467-7652.2012.00726.x

19. Becker, A. and Lange, M. (2009) VIGS-Genomics Goes Functional. Trends in Plant Science, 15, 1-4. https://doi.org/10.1016/j.tplants.2009.09.002

20. Fu, D.Q., Zhu, B.Z., Zhu, H.L., Zhang, H.X., Xie, Y.H., Jiang, W.B., Zhao, X.D. and Luo, K.B. (2006) Enhancement of Virus-Induced Gene Silencing through Low Temperature and Low Humidity in Tomato. Molecules and Cells, 121, 153-160. 